UDK 327.82(410:44)"1718"

341.382(497.11 Požarevac)"1718"

929 Sutton, Robert

Primljeno: 20. 1.2017.

Privaćeno: 1. 6. 2017.

Izvorni znanstveni rad

DOI: $10.22586 /$ pp.v52i0.4

\title{
Uloga Roberta Suttona u sazivanju i radu mirovnoga Kongresa u Požarevcu 1718. godine ${ }^{1}$
}

\author{
Marija Kocić \\ Filozofski fakultet \\ Odeljenje za istoriju \\ Univerzitet u Beogradu \\ Čika Ljubina 18-20 \\ 11000 Beograd \\ Republika Srbija \\ E-adresa: marijakocich@gmail.com \\ Nikola Samardžić \\ Odeljenje za istoriju \\ Filozofski fakultet \\ Univerzitet u Beogradu \\ Čika Ljubina 18-20 \\ 11000 Beograd \\ Republika Srbija \\ E-adresa: nsamardz@f.bg.ac.rs
}

Rad istražuje doprinos britanskoga diplomata Roberta Suttona u sazivanju Kongresa u Požarevcu kojim je završen Drugi morejski rat (1714. - 1718.). Istraživanje je zasnovano na neobjavljenoj arhivskoj građi iz Nacionalnoga arhiva u Londonu (The National Achives at Kew Gardens, London), od koje najveći dio čine izvješća Roberta Suttona. Radi utvrđivanja njihove objektivnosti u razmatranje su uzeta historiografska djela (iz iste epohe) kao i suvremena istraživanja.

Ključne riječi: Robert Sutton, Požarevac, diplomacija, Porta, Abraham Stanyan, pregovori

\footnotetext{
Rad je rezultat istraživanja na projektu Modernizacija Zapadnog Balkana (ev. br. 177009), koji financira Ministarstvo prosvete, nauke i tehnološkog razvoja Republike Srbije.
} 
Velika Britanija stekla je važnu poziciju u europskim međunarodnim odnosima zahvaljujući ishodu ratova s konca 17. i početka 18. stoljeća. Povratak vigovaca na vlast neposredno nakon izbora Georgea I. (1714. - 1727.) ojačao je položaj Velike Britanije, osobito kada je postala garant poštovanja odredaba Ugovora u Utrechtu zaključenoga 1713. godine. Francusko-britansko približavanje, od početka 1717., negativno se odrazilo na interese habsburškoga cara Karla VI. (1711. - 1740). ${ }^{2}$ Suočen s posljedicama britansko-francuskoga približavanja Karlo VI. odlučio je obustaviti primjenu Sporazuma o barijerama. To je Nizozemsku, saveznicu Velike Britanije, dovelo u nezavidan položaj.

Robert Sutton bio je jedna od važnijih osoba koje su svojim sposobnostima ukazivale na važno mjesto koje su Levant i europski jugoistok dobivali u britanskoj vanjskoj politici. ${ }^{3}$ Sutton je u Osmansko Carstvo stigao nedugo nakon završenih mirovnih pregovora u Srijemskim Karlovcima 1699. i Istanbulu 1700. godine, kojima su okončani ratovi sa Svetom ligom i Rusijom. Osmansko Carstvo trajno je potisnuto južno od velikih panonskih rijeka nakon što je habsburška vojska zaposjela Slavoniju i Ugarsku. Koncem 17. stoljeća u Osmanskome Carstvu nastupilo je razdoblje prevrata u kojima su prednjačili janjičari. Na taj način uklonjeni su Mehmed IV. 1687. i Mustafa II., a godine 1703. i sultan Ahmed III. (1703. - 1730.), koji je u jednoj takvoj pobuni i došao na vlast uz podršku velikoga vezira Çorlulu Ali-paşe (1706. - 1710.), koji je prvenstveno radio na stabilizaciji unutrašnjih prilika u državi nego na vođenju novih ratova. ${ }^{4}$ Vrijeme u kojemu je Porta diktirala međunarodne odnose postalo je nepovratna prošlost.

Uspjesi Habsburške Monarhije omogućili su i snaženje i teritorijalno širenje Rusije. Petar I. Veliki (1682./1689. - 1725.) uspio je u Bitci kod Poltave 8. srpnja 1709. poraziti švedsku vojsku, koju je predvodio kralj Karl XII. (1697. - 1718.). Porta je 18. srpnja 1709. dala Karlu XII. neku vrstu političkoga azila ne obazirući

\footnotetext{
2 Detaljnije u: Marija Kocić, Diplomatija u službi kapitala: evropske nacije na osmanskom Levantu (XVIXVIII vek) (Beograd: Hesperiaedu; Filozofski fakultet, 2014), 170-173. Ovdje je navedena dodatna literatura.

3 Robert Sutton (1671. - 1746.) prethodno je službovao u Beču gdje je stigao 1694. kao kapelan u službi tadašnjega londonskoga poslanika Roberta Suttona, drugoga baruna od Lexingtona (1662. - 1723). Dijelom zahvaljujući utjecaju baruna od Lexingtona, nakon povlačenja Williama Pagheta (1692. - 1699.) imenovan je ambasadorom na Porti. Prepiska Roberta Suttona važan je izvor neosmanske provenijencije za povijest Osmanskoga Carstva početkom 18. stoljeća: Kenneth M. Setton, Venice, Austria, and the Turks in the Seventeenth Century (Philadelphia: American Philosophical Society, 1991), 420, nap. 77. Dio njegove prepiske ranije je objavljen u: Akdes Nimet Kurat, The Despatches of Sir Robert Sutton, Ambassador in Constantinople, 1710 - 1714 (London: Royal Historical Society, 1953). Međutim, građa iz ranijih godina njegova službovanja do danas nije objavljena. O ranome razdoblju njegova boravka u osmanskoj državi vidjeti: Marija Kocić, "Engleska i Porta od mira u Sremskim Karlovcima do 'Jedrenskog događaja", Radovi Zavoda za hrvatsku povijest Filozofskoga fakulteta Sveučilišta u Zagrebu 46 (2014): 223-237.

4 Vidjeti: Marija Kocić, “Kolebanja u odnosima Porte i Evrope od 'Jedrenskog događaja' (1703) do uspostave stabilne vladavina Ahmeda III (1706)", Vojno-istorijsкi glasniк 2 (2013): 20-40.
} 
se na proteste Rusije. Karl XII. ostao je u Osmanskome Carstvu do 1714. godine predstavljajući, po Suttonovim riječima, činitelja "od velikoga značenja za ruskoosmanske odnose." Zahvaljujući njegovim poticajima i podršci francuskoga veleposlanika, Porta je nekoliko puta zaratila s Rusijom i Poljskom te time napustila politiku smirivanja. ${ }^{5}$ Njezina nova potreba da se obračuna s Venecijom pripisana je sultanu Ahmedu III. i velikome veziru Damatu Ali-paši (1713. - 1716.). Drugi morejski rat Osmanskoga Carstva i Venecije otvorio je novu krizu u jugoistočnoj Europi, posebno kada se u sukob 1716. godine uključila i Habsburška Monarhija. ${ }^{6}$ Istovremeno je novi španjolski kralj Filip V. (1700. - 1724.), poveden ambicijama kraljice Elizabete Farenze i kardinala Giulija Alberonija, nastojao obnoviti španjolski utjecaj na Apeninskome poluotoku. Španjolska flota napala je Korziku u kolovozu 1717. godine. Budući da je Italija za Beč postala prioritet nove vanjske politike, namjere španjolskoga kralja navele su Karla VI. da ubrza pregovore s Portom. ${ }^{7}$

Drugi morejski i novi Habsburško-osmanski rat mogli su ukazati kako su Levant i Jugoistok potisnuti na marginu međunarodne politike, ali je prisutnost europskih sila, u ratu ili diplomaciji, potvrdilo u kojoj su mjeri i u kome smislu procesi na tome prostoru postali paradigmatični. Prelamaleni su, udaljeni i naizgled nepovezani konteksti: prodor Habsburške Monarhije u Podunavlje, ekspanzija Rusije i Veliki sjeverni rat, budućnost Italije, uloga Francuske, interesi velikih pomorskih sila Britanije, Nizozemske i, ponovno, Španjolske. Britaniji je odgovaralo zaplitanje odnosa - i u ratu i u politici.

Robert Sutton, koji je 1702. godine službeno preuzeo dužnost britanskoga veleposlanika na Porti, izrazio je 1716. želju da bude opozvan. Umjesto njega imenovan je Edward Wothley Montagu (1716. - 1717.). Ali je, na povratku u Britaniju, dok je boravio u Beču, Suttonu stigao neočekivani nalog da se tamo zadrži i aktivno uključi u mirovne pregovore s Portom. U trenutku kada je Sutton prispio u Beč, Britanija još uvijek nije imala jasnu predodžbu koji bi ju od njezinih diplomata najuspješnije mogao zastupati u Habsburškoj Monarhiji. Pitanje je posebno dobilo na važnosti kada je postalo očigledno da Edward Wortley Montagu mora biti hitno opozvan u listopadu 1717. godine. Novi britanski veleposlanik na Porti postao je Abraham Stanyan (1718. - 1730.), dotadašnji rezident u Beču

\footnotetext{
${ }^{5}$ O položaju Karla XII. detaljnije u: Marija Kocić, Aleкsandar Rastović, "Karlo XII i Porta: pregovori око povratка u Švedsкu u svetlu englesкih izvora", Vojno-istorijski glasniк 1 (2014): 105-122.

6 Marija Kocić, "Mletačko-austrijski savez iz 1716. godine u svijetlu engleskih izvora", Zbornik Odsjeka za povijesne znanosti Zavoda za povijesne i društvene znanosti HAZU 32 (2014): 131-147.

7 Thomas Henry Dyer, A History of Modern Europe from the Fall of Constantinople (London: George Bell and Sons, 1901), IV, 202-206; Girolamo Ferrari, Delle Notizie Storiche della Lega tra l' Imperatore Carlo VI. e la Republica di Venezia Contra il Gran Sultano Acmet III. e de' loro Fatti d' armi. Dall Anno 1714. sino alla pace di Passarowitz (Venezia: Presso Carlo Buonarrigo, 1723), 257.
} 
(1716. - 1717.). ${ }^{8} \mathrm{U}$ istoj smjeni novi poslanik u Beču postao je François-Louis de Pesmes de Saint-Saphorin, ${ }^{9}$ iskusan diplomat švicarskoga podrijetla. ${ }^{10}$

Novi britanski veleposlanik Edward Worthely Montague (1716. - 1718.) stigao je u Istambul u ožujku 1717. godine u pratnji supruge Mary. ${ }^{11}$ Ideja britanskoga dvora o posredovanju zasnivala se na iskustvu mirovnih pregovora u Srijemskim Karlovcima, na kojima se Porta morala odreći svoga tradicionalnog stajališta o unilateralnoj diplomaciji. ${ }^{12}$ Montagu se nadao da će Britanija svojom medijacijom trgovcima svoje narodnosti na Levantu osigurati povlašten položaj. U tome smislu nije propustio da u službenome izvešću podsjeti da je "u godini 1622. kralj Engleske izabran od strane Porte za jedinoga medijatora u postizanju mira između nje i Poljske."13

Prvu mirovnu ponudu Porte Beču dopremio je Eugenu Savojskome, koji je u Zemunu pripremao napad na Beograd, glasnik beogradskoga dizdara Mustafapaše. Po mišljenju Girolama Ferrarija Savojski je mogao računati na pomirljivu struju na Porti, koju je predvodio kajmakam Damat İbrahim-paša. Karlu VI. i njegovim ministrima bilo je jasno da Osmansko Carstvo nije u stanju podnijeti nove ratne napore. $\mathrm{O}$ dostavljenim mirovnim prijedlozima raspravljalo se $\mathrm{u}$ Beču, a bio je uključen i venecijanski veleposlanik Pietro Grimani. ${ }^{14}$

\footnotetext{
8 Abraham Stanyan bio je diplomata sa dužom karijerom. U vreme ambasadora Williama Trumbulla (1686. - 1689.) u Osmanskom Carstvu služio je kao njegov sekretar. Zatim je imenovan za poslanika u Švajcarskoj (1705. - 1714.). S tog položaja imenovan je za poslanika u Beču. Jedno od značajnih dela koje mu se priprisuje je: L'Account of Switzerland (London, printed for Jacob Tonson, 1714).

9 Detaljnije o njemu vidjeti u: Andrew C. Thompson, "Pesme de Saint-Saphorin, François Louis de (1668-1737), diplomat and army officer", u: Oxford Dictionary of National Biography (London: Oxford, 2005) na sajtu: http://oxfordindex.oup.com/view/10.1093/ref:odnb/73886 (pregled izvršen 17. VII. 2016.).

${ }^{10}$ O njihovu odnosu tijekom boravka u Beču vidjeti: Linda Frey, Marsha Frey (prir.), The Treaties of the War of the Spanish Succession: An Historical and Critical Dictionary (London: Greenwood Press, 1995), 339.

${ }^{11}$ Edward Worthely Montague svoj je uspon dugovao dolasku vigovaca na vlast (1714.). Prva funkcija koja mu je povjerena bila je lord blagajnika (Lord Commissioner of the Treasury) na kojoj je ostao do 1715.

${ }^{12}$ O tome detaljnije u: Marija Kocić, Nikola Samardžić, "Porta na Kongresu u Karlovcu (1698 .- 99.): kraj ad hoc diplomatije", Historijski zbornik 68 (2015): 15-30. Vidjeti i: Marija Kocić, Turska u međunarodnim odnosima 1688-1699: put u evropsku diplomatiju (Beograd: Hesperiaedu, 2014), 269-280. Ovdje je navedena dodatna literatura.

${ }^{13}$ The National Archives at Kew Gardens, London (dalje: TNA), 97 [Secretaries of State: State Papers Foreign, Turkey] (dalje: SP 97) /24 [Robert Sutton, Edward Wortley Montagu, Abraham Stanyan], f. 113v; [Tatar] Pazardžik, 30. XI. 1717.; Edward Wortley Montague državnom sekretaru. Sva pisma koja su britanski diplomati slali iz Istambula u London bila su namijenjena državnim sekretarima: jednome za južne provincije, a drugome za sjeverne. Na dokumentima nije naznačeno na koga se od njih dvojice dopis precizno odnosio zbog čega je navedeno samo: "državnome sekretaru."

${ }^{14}$ Ferrari, Delle Notizie Storiche, 252.
} 
Do sredine studenoga 1717. godine Porta još uvijek nije odlučila pod kojim bi uvjetima trebalo pristupiti pregovorima. ${ }^{15}$ Bečki dvor očekivao je da će - zahvaljujući osvajanju Temišvara, Beograda (16. kolovoza 1717.) i sjeverne Srbije - ostvariti znatnu prednost u budućim pregovorima. Odnosi su, međutim, postali neočekivano složeniji nakon neuspješne opsade Zvornika, koju je izvršila habsburška vojska s namjerom da izvrši prodor u Bosnu. Pored toga, Ratni savjet odlučio je poslati pet pješadijskih i tri konjanička puka u Italiju gdje su već bile stacionirane trupe Karla VI. Vojskom u Italiji trebao je zapovijedati maršal Mercy, ali se zbog njegova narušenog zdravlja pretpostavljalo da će komanda biti prepuštena nekome drugome. ${ }^{16}$ Do novoga preokreta došlo je kada je general Petrasch osvojio Zvornik - "grad na granici između Bosne i Srbije."

Porta je bečkome dvoru ponudila razgraničenje po načelu uti possidetis, ${ }^{18}$ ali je odbijala ući u pregovore s Venecijom, a da bi Karlo VI. uvjetovao pregovore uključivanjem Venecije. ${ }^{19}$ Karlo VI. primio je Roberta Suttona u čijoj se pratnji nalazio i Abraham Stanyan. Sutton i Stanyan obavijestili su ga da su od Georgea I. dobili sve potrebne instrukcije za buduću medijaciju. ${ }^{20}$ Kada je početkom prosinca 1717. godine poruku Porte da prihvaća pregovore donio u Beč službenik Roberta Suttona, Stanyanu se u tome trenutku činilo da dvor nije u stanju donijeti važnu odluku po tome pitanju. ${ }^{21}$ Time je Suttonova uloga dodatno dobila na značenju, posebno tijekom ugovaranja preliminarnih uvjeta. Stanyan je zatim otputovao u Istambul kako bi se obavio protokol procedure opoziva veleposlanika Montagua, a on sam preuzeo je dužnostveleposlanika. Sutton je ostao u Beču.

Na Porti su bili zabrinuti i zbog stanja u vojsci. I prije pada Beograda Edward Wortley Montague slutio je moguću pobunu u pojedinim rodovima. ${ }^{22} \mathrm{Pad}$ Beograda potaknuo je nezadovoljstvo neuspjesima sultana i Porte. Posebno su se uzbunili janjičari koji su, ostajući bez plaća, napuštali utvrde koje bi trebali braniti. U Sofiji su krenuli u pljačku i razgrabili namirnice namijenjene vojsci. ${ }^{23}$

\footnotetext{
15 TNA, SP, 97/24, f. 105r; Beč, 16. XI. 1717.; Robert Sutton državnome sekretaru.

16 TNA, SP, 97/24, f. 105r-105v.

${ }^{17}$ Ferrari, Delle Notizie Storiche, 253

18 TNA, SP, 97/24, f. 151r; Beč, 15. I. 1718.; Robert Sutton državnom sekretaru.

${ }^{19}$ Ferrari, Delle Notizie Storiche, 254. e

${ }^{20}$ TNA, SP, 97/24, f. 141r; Beč, 17. XII. 1717.; Robert Sutton državnome sekretaru.

${ }^{21}$ TNA, SP, 97/24, f. 117r-117v; Beč, 24. XI. / 5. XII. 1717.; Abraham Stanyan državnome sekretaru.

22 [f. 64r] (...) It is said to an very doubtfull [ac]tion there this Grand Signor will continue or not [war]. The Number of the discontented is very great other changes said to have some generally made by a fe[a] rs of the common Janissaries or Spahis [f. 64v] who begun to cry out against the Governm[ent] and were immediately joined by their companions that had not the least notice given them what was Deisgned; TNA, SP, 97/24, f. 64r-64v; Pera u Istabmulu, 2./13. VIII. 1717.; Edward Wortley Montague državnome sekretaru.

${ }^{23}$ Ferrari, Delle Notizie Storiche, 269.
} 
Novo obavještenje o namjeri Porte da zaključi mir dostavio je francuskome dvoru veleposlanik Jean-Louis d'Usson, markiz de Bonnac (1716. - 1725.) ${ }^{24}$ Uz spoznaju o navedenoj činjenici Sutton je dodao i zabrinutost zbog upornoga odbijanja Porte da u pregovore uključi Veneciju. ${ }^{25}$ Britanska diplomacija imala je važnu ulogu u predstojećim pregovorima za razliku od one koju je dobila u Srijemskim Karlovcima. U Srijemskim Karlovcima je William Paghet bio ovlašteni britanski medijator, uz nizozemskoga veleposlanika Jakob[us]a Kolyera (1680. - 1718.). ${ }^{26}$ U pripremi novoga mirovnog kongresa aktivno su sudjelovali Montague, koji je usprkos opozivu ostao u Osmanskome Carstvu, Stanyan, koji ga je smijenio i Sutton, koji je u međuvremenu dobio nedovoljno jasne kompetencije.

Suttonova izvešća upućuju da je habsburška strana za mjesto održavanja kongresa isprva predlagala Fetislam, današnje Kladovo, dok je za mjesto boravka mletačkih pregovarača predvidjela Čermez na drugoj obali Dunava. Budući da su se pregovori trebali voditi na "ničijoj zemlji," trebalo je i sagraditi drvene kućice u kojima bi diplomati, raspoređene po "logorima", boravili tijekom trajanja kongresa. Prvobitni plan predviđao je da se pregovarači sastaju na malenome otoku na sredini rijeke. Zato je trebalo i na tome otoku pripremiti ambijent za vođenje pregovora. Također, svaka strana morala je sagraditi pontonske mostove preko kojih bi njihovi pregovarači prelazili od mjesta stanovanja do mjesta vođenja pregovora. $U$ trenutku kada je Beč iznio taj prijedlog, osmanski predstavnici stigli su u Niš. ${ }^{27}$

Habsburški predstavnici na mirovnim pregovorima bili su Damian Hugo von Virmont i bivši rezident na Porti Michael von Talman, jedna od ključnih ličnosti

${ }^{24}$ [f. 160r] (...) Tho' 'tis assured th] Marquis de Bonac hath written to the French [f. 160v] Court, that $t[h]$ Turks were so much bent upon Peace, that there was no relying on $t[h] e$ continuance of $t[h]$ e War, which I believe to have been true at that time, they may possibly have changed their disposition in some measure since, However, as His Court is resolved to carry on th] $\mathrm{e}$ Treaty as far as it will go, \& $\mathrm{t}[\mathrm{h}] \mathrm{e}$ Turks continue to be desirous of Peace; TNA, SP, 97/24, f. 160r-160v; Beč, 2. II. 1718.; Robert Sutton državnome sekretaru. Markiz de Bonnac kršten je u Bonaku 19. svibnja 1674., a umro u Parizu 1. rujna 1738. godine. Izabran je za veleposlanika u Osmanskome Carstvu 30. svibnja 1716. godine. U Istambul je stigao 4. listopada 1716., a opozvan je 30. studenoga 1724. godine, ali je Istambul napustio tek 26. veljače 1726. godine: Anne Mézin, Les consuls de France au siècle des lumières (1715-1792) (Paris: Imprimerie nationale, 1997), 148, nap. 5. Njegovo najvažnije djelo ujedno rasvetljava položaj Francuske na Leantu u ovome periodu. Vidjeti: Jean- Louis d'Usson, marquis de Bonnac, Mémoire historique sur l'ambassade de France à Constantinople, [ed.], Service diplomatique et consulaire français (Paris: E. Leroux, 1894).

${ }^{25}$ TNA, SP, 97/24, f. 162v; Beč, 22. II. 1718.; Robert Sutton državnome sekretaru.

${ }^{26}$ Jakob Kolyer bio je sin nizozemskoga rezidenta Justin[us]a Kolyera (oko 1669. - 1680.), kojemu je pomagao kao sekretar. Nakon očeve smrti naslijedio ga je na položaju, ali je uskoro uspio dobiti status veleposlanika. Tijekom njegove ambasade nizozemska trgovina na Levantu ostvarila je vidan napredak. O tome u: Kocić, Diplomatija u službi kapitala, 87-90. O ulozi Jakoba Kolyera u pripremi i pregovorima u Srijemskim Karlovicma vidjeti: Kocić, Turska u međunarodnim odnosima, 262 i dalje. Kasnije je njegov ugled među diplomatima diskreditiran pod utjecajem optužbi da je bio ruski špijun i radio u njihovome interesu. O tome svjedoči nekoliko dokumenata u: TNA, SP, 97/23 [Constantinople. Sir Rob[er]t Sutton. from 31th Jan[a]ry 1713. to 10th May 1716.].

27 TNA, SP, 97/24, f. 163r; Beč 22. II. 1718.; Robert Sutton državnome sekretaru. 
u Ratnome savjetu. Mletački Senat odlučio je da u pregovorima sudjeluje Carlo Ruzzini, a da mu pomaže sekretar Vendramin Bianchi. ${ }^{28}$ Portu su predstavljali silhadar İbrahim-ağa i Yirmisekiz Çelebi Mehmed-efendija, ${ }^{29}$ koji su 6. travnja 1718. dobili sultanove upute i ovlasti. ${ }^{30}$

U historiografskim zapisima nastalim tijekom 18. stoljeća, od svih britanskih predstavnika uključenih u rad mirovnih pregovora 1718. godine, isključivo se spominje Robert Sutton. ${ }^{31}$ Njegovu ulogu opterećivao je, međutim, status diplomata u opozivu, koji je neposredno imenovan za medijatora: povučen je s Porte, a na njegovo mjesto imenovan je Montagu, dok je u Beču postavljen Saint-Saphorin. Zbog toga Sutton u trenutku pokretanja pregovora nije imao na raspolaganju tumača za osmanski turski jezik. Tu priliku s uspjehom je iskoristio Dubrovčanin Luka Chirico, ${ }^{32}$ koji je uspio u svojstvu tumača ući u sastav britanske delegacije. ${ }^{33}$ Posljednje pismo koje je Sutton poslao iz Beča ukazuje da ga je habsburški dvor pritiskao kako bi pregovori hitno krenuli. Prvi predstavnik Karla VI. grof Virmont trebao je napustiti Beč 16. odnosno 17. travnja. Carlo Ruzzini, koji je u Beč stigao 12. travnja, ubrzo je produžio prema mjestu održavanja kongresa. ${ }^{34}$ Karlo VI. odlučio je da ne narušava primirje s Portom koje je predložio grof Kolyer, a koji je za to imao Portine ovlasti. Sutton je, pak, bio uvjeren da habsburška vojska neće poduzimati nove akcije do kraja svibnja do kada bi, po njegovu mišljenju, mir trebalo biti zaključen. ${ }^{35}$

Nakon prvobitnih naznaka o Fetislamu kao mjestu održavanja mirovnoga kongresa, Sutton je inzistirao na slobodnome prostoru između Požarevca i gradića

\footnotetext{
${ }^{28}$ O svome sudjelovanju u pregovorima u Požarevcu ostavio je svedočenje: Vendramin Bianchi, Istorica Relazione della pace di Passarovitz (Padua: Manfrè, 1719).

${ }^{29}$ Christophe-Guillaume de Koch, Abbrégé de l'histoire des traités de paix entre les puissances de L'Europe depuis la Paix de Westphalie, vol. I-IV (Basle; Paris; Strasbourg; Leipsic: Chez J. Decker, 1797), IV, 44.

${ }^{30}$ Rhoads Murphey, "Twists and Turns in the Diplomatic Dialogue: the Politics of Peacemaking in the Early Eighteenth Century", u: The Peace of Passarowitz, 1718, ur. Charles Ingrao, Nikola Samardžić, Jovan Pešalj (West Laffayete: Purdue University Press, 2011), 73-92.

${ }^{31}$ François C. Le Roy de Lozembrune, Histoire de la Guerre de Hongrie pendant les campagnes de 1716, 1717 et 1718. Orneé du Plan de Belgrade assigee en 1717 (Vienne: Chez Graeffer Le Jeune, 1788), 218; De Koch, Abbrégé de l'histoire des traités de paix, IV, 44.

${ }^{32}$ Luka Chirico rođen je 28. veljače 1684. od oca Gaetana i majke Kate Barca. Gavro Škrivanić naveo je da je Chirico nakon završetka konzularne službe ostao živjeti u Istambulu. Kao konzul spominje se 1709. -1744. godine; Gavro Škrivanić, Dnevnik Dubrovčanina Mihajla Pešića o Požarevačkom mirovnom kongresu 1718 godine (Beograd: Istoriski institut SAN, 1952), 2. Nedavna istraživanja utemeljena na dubrovačkoj arhivskoj građi ukazuju da je preminuo 1749. godine u Istambulu; Vesna Miović, Dubrovačka diplomacija u Istambulu (Zagreb; Dubrovnik: Zavod za povijesne znanosti HAZU u Dubrovniku, 2003), 116. S izvešćima Luke Chirica bio je upoznat Bogumil Hrabak, koji ih je koristio u pojedinim radovima: Bogumil Hrabak, "Političke i trgovinske prilike srednjeg Podunavlja 1683 - 1739. prema dubrovačkim i kotorskim podacima”, Zbornik Matice Srpske za istoriju 45 (1992): 101-102.

${ }^{33}$ Škrivanić, Dnevnik Dubrovčanina Mihajla Pešića, 5.

${ }^{34}$ TNA, SP, 97/24, f. 205r; Beč, 13. IV. 1718., Robert Sutton državnome sekretaru.

${ }^{35}$ TNA, SP, 97/24, f. 205r.
} 
Ram. ${ }^{36} \mathrm{U}$ međuvremenu mu je dostavljeno pismo Jakoba Kolyera, koji ga je obavijestio da uskoro stiže u Niš gdje se trebao sastati s osmanskom delegacijom, koja je preko Vidina putovala za Kladovo. ${ }^{37} \mathrm{Na}$ kraju su sve strane prihvatile Suttonov prijedlog da se pregovori vode u Požarevcu, "malenome selu u Srbiji, smještenom na Moravi." ${ }^{38}$ Međutim, Girolamo Ferrari tvrdio je da su barun Enninghen i Mustafa-ağa za mjesto pregovora izabrali brisani prostor između Požarevca i Rampalanke, koji je bio pust, bez stanovnika, zbog čega je "na ovome terenu moglo sve proteći mirno i u općoj sigurnosti." ${ }^{39}$

Dok su se vodili preliminarni pregovori u logor u blizini Požarevca stigla je vijest o padu velikoga vezira Nişancı Mehmed-paše (1717. - 1718.). Za novoga velikog vezira izabran je zet i miljenik Ahmeda III., dotadašnji zamjenik (kaymakam) velikoga vezira, Damat İbrahim-paša (1718. - 1730.). Pojedini izvori tvrde da je Nişancı Mehmed-paša planirao ukloniti kaymakama i da je ovaj uzvratio izvevši prevrat. Odmah po stupanju na položaj Damat İbrahim-paša u Edirni je obavio razgovor s Abrahamom Stanyanom otkrivši mu da je njegov prethodnik uklonjen jer se opirao sklapanju mira. Time je ujedno ukazao na namjere Ahmeda III. koji je - dovodeći svoga drugog zeta na položaj velikoga vezira - smatrao da će time ubrzati pregovore. ${ }^{40}$ Izbor Damat İbrahim-paše dao je u isto vrijeme i priliku osmanskim predstavnicima u mirovnim pregovorima da se nadaju širim ovlastima Porte.

Prvi dogovor, postignut konsenzusom, odnosio se na mjesto održavanja kongresa. Potom su Beč i Porta odredili po jednoga predstavnika da otputuje u Požarevac i obilježi mjesto održavanja pregovora. ${ }^{41} \mathrm{~S}$ već definiranom ulogom medijatora Robert Sutton stigao je u Beograd 27. travnja 1718. gdje su ga gradske vlasti dočekale počasnom paljbom. Održavao je stalnu prepisku s Jakobom Kolyerom. Kolyer se u Požarevac uputio iz Niša, preko Jagodine, gdje je počinjao teritorij pod habsburškom okupacijom. Sutton je očekivao da će konferencija krenuti za nekoliko dana iako je znao da osmanska delegacija ne posjeduje dovoljno široke

\footnotetext{
${ }^{36}$ Mjesto na Dunavu. Palanka je u osmanskome periodu bila drvena utvrda namijenjena smještaju trupa na važnoj komunikaciji ili granici. Do početka XIX. stoljeća promijenila je svoje prvobitno značenje u procesu označenome "slaviziranjem varoši"; Marija Kocić, Orijentalizacija materijalne kulture na Balkanu. Osmanski period XV-XIX vek (Beograd: Hesperiaedu; Filozofski fakultet, 2010), 32.

37 TNA, SP, 97/24, f. 205r-205v.

38 de Lozembrune, Histoire de la Guerre de Hongrie pendant les campagnes de 1716, 1717 et 1718., 218.

${ }^{39}$ Ferrari, Delle Notizie Storiche, 281.

${ }^{40}$ [f. 227r] ... M[yste]r Stanyan writes me from Adrianople under the 29th past O. S. that the New Vizir had desired him to acquaint me, that his predecessour was removed from no other reason but his not being so well inclined to peace as the Gr[and] Sig[no]r wished \& therefore that this change would be so far from making any in his measures towards it, that it would be a means of finishin $\mathrm{t}[\mathrm{h}] \mathrm{e}$ Negotiation much sooner by removing the chief obstacle thereto; TNA, SP, 97/24, f. 227r; logor nedaleko od Požarevca, 22. V. 1718.; Robert Sutton državnome sekretaru.

${ }^{41}$ TNA, SP, 97/24, f. 213r-213v; Beograd, 29. IV. 1718.; Robert Sutton državnome sekretaru.
} 
ovlasti na osnovi kojih bi, ako bi htjela odgovoriti na zahtjeve Venecije, mogla i zaključiti mir po načelu uti possidetis. ${ }^{42}$

Pregovarači su počeli stizati u Požarevac 6. svibnja $1718 .{ }^{43}$ Prvi je doputovao nizozemski veleposlanik Jakob Kolyer. Sutton se 4. svibnja nalazio u blizini toga mjesta. Vodio je i sekretara i tumača. U Požarevac je stigao 7. svibnja. ${ }^{44}$ Jakobu Kolyeru pomagao je Nicolò Teylis, sin dugogodišnjega tumača nizozemskoga veleposlanstva na Porti, i njegov rođak Fontana.$^{45}$ Sutton je imao priliku dobro upoznati Kolyerove stavove i ponašanje tijekom godina koje je proveo kao britanski veleposlanik na Porti. On je izgleda imao mnogo više povjerenja u njega nego u Edwarda Wortleya Montagua, koji prema njemu od prvih dana nije pokazivao nimalo poštovanja.

Sjedećih nekoliko dana Sutton je proveo posjećujući logore (Quarters) pregovaračkih strana i baveći se utvrđivanjem protokola. Osmanska delegacija je 8. svibnja podigla šatore, u čijoj je blizini bio smješten Jacob Kolyer. Grof Virmont i Carlo Ruzzini pojavili su se jednoga od sljedećih dana zauzevši svoje "logore," koje je ranije odredio grof Talman. Međutim, osmanski predstavnici odbili su ostati u mjestu predviđenome za njihov boravak pod izgovorom da su udaljeni od izvora pitke vode i namirnica. Zbog toga se morao za njih izabrati novi "logor." 46 Logori medijatora bili su tri četvrt sata hoda udaljeni od logora pregovarača, dok je od jednoga od drugoga logora pregovarača udaljenost bila sat vremena hoda. Nakon što su otklonjeni nesporazumi oko smještaja delegacija, pristupilo se preispitivanju uloge osmanskih pregovarača. Sutton je nastavio inzistirati da oni prije otvaranja kongresa dobiju šire ovlasti.

Uloga Roberta Suttona na usklađivanju zahtjeva habsburških i osmanskih predstavnika nije bila jednostavna. Nesuglasice su se javile i oko titulature u službenim dokumentima. Sutton je naveo da su se predstavnici Karla VI. žalili na tituliranje svoga vladara u službenome osmanskom dokumentu kao Nemce chiassar (njemački kralj) umjesto Roman Imperatore (rimski car), kako je zahtijevao Beč. ${ }^{47}$ Osmanski predstavnici tražili su da pregovori budu odmah pokrenuti tvrdeći da

\footnotetext{
${ }^{42}$ TNA, SP, 97/24, f. 213v.

${ }^{43}$ Škrivanić, Dnevnik Dubrovčanina Mihajla Pešića, 6.

${ }^{44}$ Isto, 22.

${ }^{45}$ Isto, 31 .

${ }^{46}$ TNA, SP, 97/24, f. 223r; logor u blizini Požarevca, 16. V. 1718.; Robert Sutton državnome sekretaru.

${ }^{47}$ [f. 223v] (.).. But the Emp[ero]r's Amb[assadou]r's Plenip[otentiarie]s made two exceptions thereto, the one against the Title of Nemce Chiassar of German Cesare instead of which they required that of Roma[n] Imperatore, which the Gr[and] Sig[no]r hath several times given the Emp[ero]r in his letters; the Other against the omission of the Gr[and] Sig[no]r's Hattihumaiun or signature will his own hand, w[hi]ch has newer been practiced on such occasions, \& is not the stile of the Port; TNA, SP, 97/24, f. 223v. Transkripcija teksta izvršena je prema tadašnjemu stilu koji su britanski diplomati koristili u svojoj prepisci. Hatihumajun (tur. hatt-ı hümayün) - pismena naredba sultana najčešće adresirana na nekoga provincijskog upravnika, činovnike ili podanike.
} 
posjeduju sve potrebne ovlasti. Sutton je, međutim, smatrao da to nije točno i da je njihova namjera odugovlačenje pregovora. Po Suttonovu mišljenju nakon smrti velikoga dragomana Alessandra Maurocordata ${ }^{48}$ na Porti nije bilo osobe koja bi bila u stanju sultanu i vezirima predočiti "probleme s ovlastima." Osmanski predstavnici za eventualni manjak ovlasti krivili su medijatore smatrajući da su oni mogli dati bolje instrukcije Porti. ${ }^{49}$ Zbog toga su osmanski predstavnici 15. svibnja 1718. poslali u Niš glasnika po šire ovlasti. Njegov povratak očekivao se za 20 do 25 dana. To je Suttonu dalo dovoljno vremena da piše velikome veziru i kaymakamu o potrebi da svojim predstavnicima pošalju šire ovlasti na osnovi kojih bi Veneciji mogli ponuditi povoljnije uvjete. Prethodno su osmanski predstavnici dobili nalog Porte da inzistiraju kod druge strane na obustavi svih neprijateljstava dok pregovori budu trajali. Sutton ih je morao uvjeravati da habsburška vojska neće poduzimati nove operacije dok ne budu ugovorene osnovne mirovne točke. ${ }^{50}$

U tijeku mirovnoga kongresa Britanija je otkrivala da je prvenstveno zainteresirana za povoljan ishod Velikoga sjevernog rata. Levant je za nju izgubio nekadašnje značenje. Švedska je bila smetnja razvoju britanske i nizozemske baltičke trgovine. Britanija i Nizozemska usuglasile su svoje interese na Baltiku, dok je Danska nastojala unaprijediti svoj položaj nudeći flotu kao zaštitu nizozemskim brodovima. ${ }^{51}$ Nadajući se obustavi neprijateljstava na Baltiku, Britanija je saznala da je Petar I. odlučio poslati vicekancelara Šafirova da ugovori mir sa Švedskom. ${ }^{52}$ U isto vrijeme strepila je od odluke Filipa V. da pošalje trideset tisuća vojnika, uključujući i šest tisuća draguna, u Italiju. Filip V. se, štoviše, obratio pojedinim talijanskim državama za zajam u visini od milijun dukata. ${ }^{53}$ Time je uveo Italiju u novi rat, koji je imao posljedice i na opće europske međunarodne odnose.

Posljednjega dana svibnja 1718. godine u Požarevac su stigle nove ovlasti Porte namijenjene njezinim predstavnicima, koje su se u jednakoj mjeri odnosile na pregovore s Venecijom i s predstavnicima Karla VI. Habsburška i mletačka strana bile su zadovoljne činjenicom da je Porta odlučila prihvatiti načelo uti possidetis. Osmanski predstavnici uvjeravali su Suttona da su na osnovi novih ovlasti bili spremni pregovarati i s Venecijom. Prijevod novih Portinih ovlasti Sutton je potom poslao predstavnicima Karla VI. i Venecije. ${ }^{54}$

\footnotetext{
${ }^{48}$ O njemu detaljnije u: Kocić, Diplomatija u službi kapitala, 48. Ovdje je navedena dodatna literatura.

${ }^{49}$ TNA, SP, 97/24, f. 224r; logor u blizini Požarevca, 16. V. 1718.; Robert Sutton državnome sekretaru.

${ }^{50}$ TNA, SP, 97/24, f. 224r.

${ }^{51}$ Henry Paton, Report on the Manuscripts of Lord Polwarth. Preserved at Mertoun House. Berwickshire, vol. I-II, [ed.] Historical Manuscripts Commission (London: Published by His Majesty's Stationery Office, 1911.), I, 512; Kuyk Bay; 9. VI. 1718.; Sir John Norris lordu Cadoganu.

${ }^{52}$ Isto, 514; London, 10./21. VI. 1718.; John Roberthon lordu Polwarthu.

${ }^{53}$ Isto, 514; London, 13./24. VI. 1718.; John Roberthon lordu Polwarthu.

${ }^{54}$ TNA, SP, 97/24, f. 239r; logor nedaleko od Požarevca, 6. VI. 1718.; Robert Sutton državnome sekretaru.
} 
Mirovni kongres u Požarevcu svečano je otvoren 5. lipnja $1718 .{ }^{55}$ Nakon razmjene punomoći započela je prva konferencija. ${ }^{56}$ Kongres je zapravo počeo raditi tek pošto je Porta pristala da Venecija bude punopravno uključena. ${ }^{57} \mathrm{Na}$ jednome mjestu okupili su se i pregovarači i medijatori. Predstavnici Porte i Karla VI. oko 11 sati razmijenili su izjave da će se pridržavati načela uti possidetis. Posebno su na tome inzistirali venecijanski predstavnici. ${ }^{58}$

Prvi sukob tijekom rada kongresa nastao je oko prava prvenstva. Habsburška i osmanska delegacija jednako su zahtijevale to pravo za svoje predstavnike, ali je na koncu odlučeno da se prvenstvo prepusti osmanskoj strani. Pravo prvenstva dobilo je veliki značenje u diplomatskome protokolu 17. stoljeća. Na njemu su inzistirali pretežno predstavnici država koje su u prethodnome razdoblju ostvarile određenu prevlast u međunarodnim odnosima, dok su države u usponu nastojale da im to pravo ospore. ${ }^{59}$ Sutton je, međutim, inzistirao da se prethodno odobri zahtjev Karla VI. da Porta isporuči Ferenca II. Rákóczija (1704. - 1711.) i ostale ugarske pobunjenike koji su boravili na osmanskome teritoriju. ${ }^{60}$ Osmanski predstavnici relativno su brzo pristali uz obećanje da im ubuduće Porta neće davati utočište. ${ }^{61}$ Osmanska strana uzvratila je zahtjevom o prestanku svih neprijateljstava dok kongres bude trajao, ali su ostale strane to odbile. Kada su osmanski pregovarači zahtjev ponovili, predstavnici Karla VI. napustili su pregovore, čime je okončan prvi radni dan kongresa. ${ }^{62}$

Sukob nije spriječio dvije sukobljene strane da na kraju zasjedanja razmijene uljudne znake međusobnoga poštovanja. Grof Virmont poslao je osmanskim predstavnicima čokoladu i osvježenje, a ovi su uzvratili ponudom kave, parfema i drugih malenih darova. ${ }^{63}$ Izvješća Mihajla Pešića, koji je zastupao Dubrovačku Republiku u Požarevcu, dodatno objašnjavaju pojedinosti iz tijeka pregovora. Ne uspijevajući proniknuti u pravi razlog, Pešić je javio da se sljedećega dana Sutton nije pojavio za pregovaračkim stolom “jer je bio zauzet pisanjem izvješća." ${ }^{4}$ To je

\footnotetext{
55 Škrivanić, Dnevnik Dubrovčanina Mihajla Pešića, 6.

56 TNA, SP, 97/24, f. 239r.

${ }^{57}$ Nikola Samardžić, “The Peace of Passarowitz, 1718: An Introduction”, u: The Peace of Passarowitz, 1718, ur. Charles Ingrao, Nikola Samardžić, Jovan Pešalj (West Laffayete: Purdue University Press, 2011), 16.

58 TNA, SP, 97/24, f. 239v.

${ }^{59}$ Detaljnije u: Murphey, “Twists and Turns in the Diplomatic Dialogue”, 87. O sličnim slučajevima vidjeti: Kocić, Diplomatija u službi kapitala, 27-28.

${ }^{60}$ TNA, SP, 97/24, f. 240r; logor nedaleko od Požarevca, 6. VI. 1718.; Robert Sutton državnome sekretaru.

61 TNA, SP, 97/24, f. 240r.

62 TNA, SP, 97/24, f. 240r.

63 TNA, SP, 97/24, f. 240r.

${ }^{64}$ Škrivanić, Dnevnik Dubrovčanina Mihajla Pešića, 32.
} 
potvrdio i sam Sutton u pismu upućenome istoga dana u London. ${ }^{65} \mathrm{U}$ tome trenutku procijenio je da se pregovaračima Karla VI. ne žuri i da čekaju da mletačka strana iznese svoje zahtjeve. ${ }^{66}$

Druga konferencija održana je 7. lipnja. Tom prilikom osmanski predstavnici ponudili su više nego što je druga strana očekivala. Porta je bila spremna da se odrekne teritorija od Beograda do Morave, otoka Oršave, Banjice, Gradiške i Rama, većega dijela Vlaške, a Veneciji da ustupi otoke Čerigo i Tino (Tenedos). Grof Virmont, nazrijevši da je Porta spremna na nova popuštanja, iznio je dodatne zahtjeve. Karlo VI. inače je poslao instrukcije svojim predstavnicima u Požarevcu da ubrzaju pregovore i pretpostavljalo se da se neprijateljstva neće obnoviti. ${ }^{67}$

Sutton je 8. lipnja odlučio da se povuče u Požarevac i pošalje svoga sekretara u Beč. Kako Mihajlo Pešić toga dana nije prisustvovao pregovorima, nije mogao ni nazrijeti pravi razlog Suttonove odluke. ${ }^{68} \mathrm{~S}$ druge strane, čitajući Pešićev dnevnik o pregovorima u Požarevcu, stječe se dojam da se tijekom najmučnijih trenutaka $i$ iskušenja za sve strane, uz gotovo nepremostive nesuglasice, Sutton rijetko spominje. Na jedno od objašnjenja sredinom 20. stoljeća ukazao je i Gavro Škrivanić. On je, naime, uočio da je između Mihajla Pešića i Luke Chirica vladala netrpeljivost "zbog izvjesnih Chiricovih naprasitih i neodmjerenih ispada." ${ }^{69}$ Luka Chirico službovao je godinama kao konzul Dubrovačke Republike u Istambulu gdje je posjedovao i kuću. ${ }^{70}$ Kako je Suttonu nakon imenovanja za medijatora nedostajao prevoditelj za turski jezik, Chirico mu je ponudio svoje usluge. To bi mogao biti jedan od razloga zašto se Sutton u izvješćima Mihajla Pešića rijetko spominje.

Prvo iduće pismo Roberta Suttona od 23. srpnja 1718. nastalo je neposredno nakon što je zaključen rad Kongresa u Požarevcu. U kratkim crtama iznio je osvrt na opće stanje pregovora i njihov krajnji ishod. Posebno je istaknuo činjenicu da je od početka bio prisiljen da, navodno, ponese sav teret pregovora. Uz objašnjenje da je morao održavati stalnu prepisku s velikim vezirom, istovremeno je nudio i ispriku dvoru zašto se nije češće javljao. ${ }^{71}$ Jedan od rijetkih suvremenika, koji su tumačeći Kongres u Požarevcu ocijenili i ulogu medijatora Suttona, bio je

\footnotetext{
${ }_{65}$ TNA, SP, 97/24, f. 239r-240r.

66 TNA, SP, 97/24, f. 240r.

${ }^{67}$ Paton, Report on the Manuscripts of Lord Polwarth, I, 526; ?, 5. VII. 1718.; John Roberton lordu Polwatrhu.

${ }^{68}$ Škrivanić, Dnevnik Dubrovčanina Mihajla Pešića, 32.

${ }^{69}$ Isto, 5.

${ }^{70}$ Isto, 2.

${ }^{71}$ [f. 264r] Since the Opening of the Conferences in so pressing a Conjuncture I have been forced to bear the whole weight \& trouble of the Negotiation, which joined to the Correspondence of long Letters, w[hi]ch it was absolutely necessary to keep with the Prime Vizir, gave me so much occupation \& distraction, that I have not been able to give you regular acc[oun]ts of what passed at this Congresse...; TNA, SP, 97/24, f. 264r; Požarevac, 23. VII. 1718.; Robert Sutton državnome sekretaru.
} 
Aubrey de la Motraye. On je naveo da je Sutton postigao čudo "privoljevši muslimane da se odreknu Beograda." ${ }^{2}$

Ugovor u Požarevcu zaključen je 21. srpnja 1718. između Habsburške Monarhije i Venecije s jedne te Osmanskoga Carstva s druge strane. Kako je još sredinom 19. stoljeća ukazao Joseph von Hammer, Ugovor u Požarevcu bio je "najsjajniji i najpovoljniji mir koji je Austrija ikada zaključila s Portom." ${ }^{73}$ Nakon dvanaest konferencija održanih tijekom sedamdeset dana pregovora uslijedilo je olakšanje na svim stranama. "Ljudi su se grlili, a iz topova odjekivala je vijest o miru preko Morave i Dunava." ${ }^{.74}$ Kopije ugovora Sutton je poslao u London. U Požarevcu se zadržao do ratifikacije ugovora. ${ }^{75}$ Njihova razmjena obavljena je 21 . kolovoza $1718 .^{76}$ Tri dana kasnije Sutton je napustio Požarevac. U Beč je stigao 9.rujna i nastavio za London sredinom listopada. ${ }^{77}$

Nakon povratka u Britaniju Robert Sutton ostao je u diplomaciji. Odlukom kralja Georgea I. imenovan je 25. travnja 1720. veleposlanikom u Parizu uz otpremninu od tristo funti sterlinga i redovitu isplatu od dvije funte dnevno, uz napomenu da mu na tome položaju ne pripadaju drugi izvanredni rashodi. ${ }^{78}$

\section{Zaključak}

Medijacija Roberta Suttona na pregovorima u Požarevcu 1718. bila je potvrda nove uloge Velike Britanije u međunarodnim odnosima. Približavanje Britaniji, koje je prethodilo, ukazalo je na preokret francuske vanjske politike prijeteći da poremeti relativno dobre odnose Britanije i Habsburške monarhije. Od posljednjih desetljeća 17. stoljeća za London je od najvećega značenja bilo savezništvo $\mathrm{s}$ Bečom. Bio je to i jedan od povoda britanskoj odluci da za medijatora u mirovnim pregovorima izabere bivšega veleposlanika na Porti Roberta Suttona. Dok su se ugovarali preliminarni uvjeti, Suttonov položaj nije bio u definiran, ali su njegovo iskustvo i diplomatski kredibilitet bili dovoljni kako bi ga uvažavale obje sukobljene strane. Velika Britanija je prije svega namjeravala njegovim posredovanjem ubrzati pregovore, zabrinuta boravkom ruske vojske u Meklenburgu i jačanjem ruske pozicije na Baltiku kao i novim ambicijama Španjolske u Italiji.

\footnotetext{
${ }_{72}$ A[ubrey] de La Motraye, Travels through Europe, Asia, and into part of Africa, vol. I-III (London: Printed for the Author, 1723.), II, Apendix, 66.

${ }^{73}$ Joseph von Hammer, Historija Turskog /Osmanskog/ carstva, vol. I-III (Zagreb: Štamparski zavod “Ognjen Prica”, 1979), III, 123.

${ }^{74}$ Isto, 121-122

${ }^{75}$ TNA, SP, 97/24, f. 264v; Požarevac, 23. VII. 1718.; Robert Sutton državnome sekretaru.

${ }^{76}$ TNA, SP, 97/24, f. 276r; Požarevac, 22. VIII. 1718.; Robert Sutton državnome sekretaru.

77 TNA, SP, 97/24, f. 302r; Beč, 15. X. 1718.; Robert Sutton državnome sekretaru.

78 TNA, SP, Domestic 36/ 5[George II], f. 214; London, 18. III 1728.; popis isplata koje je britanski dvor namijenio svojim diplomatskim predstavnicima akreditiranim u drugim državama.
} 
Izvješća Roberta Suttona britanskoj vladi potvrđuju da je tijekom pregovora u Požarevcu 1718. primijenjen isti diplomatski protokol kao i na Konferenciji u Srijemskim Karlovcima 1699. godine. Njihovim prihvaćanjem Porta je prisiljena poštovati običaje europske diplomacije, a time i svoje protivnike i medijatore. Velikoj Britaniji odgovaralo je i potiskivanje Venecije s Levanta, koje je najavio Ugovor u Požarevcu. Time je omogućeno britanskim trgovcima da počnu preuzimati njezin dio levantskoga tržišta. 


\section{Izvori}

Velika Britanija - The National Archives at Kew Gardens, London (TNA) - 97

- Secretaries of State: State Papers Foreign, Turkey (SP, 97)

Velika Britanija - The National Archives at Kew Gardens, London (TNA) - 24 Robert Sutton, Edward Wortley Montagu, Abraham Stanyan.

Velika Britanija - The National Archives at Kew Gardens, London (TNA) - 36 SP, Domestic

Velika Britanija - The National Archives at Kew Gardens, London (TNA) - 5 George II.

\section{Objavljeni izvori i literatura}

Bianchi, Vendramin. Istorica Relazione della pace di Passarovitz. Padua: Manfrè, 1719.

d'Usson, marquis de Bonnac, Jean-Louis. Mémoire historique sur l'ambassade de France à Constantinople, [ed.], Service diplomatique et consulaire français. Paris: E. Leroux, 1894.

de Koch, Christophe-Guillaume. Abbrégé de l'histoire des traités de paix entre les puissances de L'Europe depuis la Paix de Westphalie, vol. I-IV. Basle; Paris; Strasbourg; Leipsic: Chez J. Decker, 1797.

de La Motraye, A[ubrey]. Travels through Europe, Asia, and into part of Africa, vol. I-III. London: Printed for the Author, 1723.

Dyer, Thomas Henry. A History of Modern Europe from the Fall of Constantinople, vol. I-IV. London: George Bell and Sons, 1901.

Ferari, Girolamo. Delle Notizie Storiche della Lega tra l'Imperatore Carlo VI. e la Republica di Venezia Contra il Gran Sultano Acmet III. e de' loro Fatti d' armi. Dall' Anno 1714. sino alla pace di Passarowitz. Venezia: Presso Carlo Buonarrigo, 1723.

Frey, Linda; Frey, Marsha. The Treaties of the War of the Spanish Succession: An Historical and Critical Dictionary. London: Greenwood Press, 1995.

Hrabak, Bogumil. "Političke i trgovinske prilike srednjeg Podunavlja 1683 - 1739. prema dubrovačkim i kotorskim podacima”. Zbornik Matice Srpske za istoriju 45 (1992): 101-102.

Kocić, Marija. Diplomatija u službi kapitala: evropske nacije na osmanskom Levantu (XVI-XVIII vek). Beograd: Hesperiaedu; Filozofski fakultet, 2014.

Kocić, Marija. "Engleska i Porta od mira u Sremskim Karlovcima do 'Jedrenskog događaja". Radovi Zavoda za hrvatsku povijest Filozofskog fakulteta Sveučilišta u Zagrebu 46 (2014): 223-237. 
Kocić, Marija. "Kolebanja u odnosima Porte i Evrope od 'Jedrenskog događaja' (1703) do uspostave stabilne vladavine Ahmeda III (1706)". Vojno-istorijski glasnik 2 (2013): 20-40.

Kocić, Marija. "Mletačko-austrijski savez iz 1716. godine u svijetlu engleskih izvora". Zbornik Odsjeka za povijesne znanosti Zavoda za povijesne i društvene znanosti HAZU 32 (2014): 131-147.

Kocić, Marija. Orijentalizacija materijalne kulture na Balkanu. Osmanski period $X V$-XIX vek. Beograd: Hesperiaedu; Filozofski fakultet, 2010.

Kocić, Marija. Turska u međunarodnim odnosima 1688-1699: put u evropsku diplomatiju. Beograd: Hesperiaedu, 2014.

Kocić, Marija; Rastović, Aleksandar. "Karlo XII i Porta: pregovori oko povratka u Švedsku u svetlu engleskih izvora”. Vojno-istorijski glasnik 1 (2014): 105-122.

Kocić, Marija; Samardžić, Nikola. "Porta na Kongresu u Karlovcu (1698. - 99.): kraj ad hoc diplomatije". Historijski zbornik 68 (2015): 15-30.

Kurat, Akdes Nimet. The Despatches of Sir Robert Sutton, Ambassador in Constantinople, 1710-1714. London: Royal Historical Society, 1953.

Le Roy de Lozembrune, François C. Histoire de la Guerre de Hongrie pendant les campagnes de 1716, 1717 et 1718. Orneé du Plan de Belgrade assigee en 1717. Vienne: Chez Graeffer Le Jeune, 1788.

Mézin, Anne. Les consuls de France au siècle des lumières (1715-1792). Paris: Imprimerie nationale, 1997.

Miović, Vesna. Dubrovačka diplomacija u Istambulu, Zagreb; Dubrovnik: Zavod za povijesne znanosti HAZU u Dubrovniku, 2003.

Murphey, Rhoads. "Twists and Turns in the Diplomatic Dialogue: the Politics of Peacemaking in the Early Eighteenth Century". U: The Peace of Passarowitz, 1718, ur. Charles Ingrao; Nikola Samardžić; Jovan Pešalj, 73-92. West Laffayete: Purdue University Press, 2011.

Paton, Henry. Report on the Manuscripts of Lord Polwarth. Preserved at Mertoun House. Berwickshire, vol. I-II, [ed.] Historical Manuscripts Commission. London: Published by His Majesty's Stationery Office, 1911.

Samardžić, Nikola. "The Peace of Passarowitz, 1718: An Introduction”. U: The Peace of Passarowitz, 1718, ur. Charles Ingrao; Nikola Samardžić; Jovan Pešalj, 9-38. West Laffayete: Purdue University Press, 2011.

Setton, Kenneth M. Venice, Austria, and the Turks in the Seventeenth Century. Philadelphia: American Philosophical Society, 1991.

Stanyan, Abraham. L'Account of Switzerland. London: Printed for Jacob Tonson, 1714. 


\title{
The Role of Robert Sutton in Convening and Functioning of the 1718 Passarowitz Peace Conference
}

\author{
Marija Kocić \\ Department of History \\ Faculty of Philosophy \\ University of Belgrade \\ Čika Ljubina 18-20 \\ 11000 Belgrade \\ Serbia \\ E-mail: marijakocich@gmail.com \\ Nikola Samardžić \\ Department of History \\ Faculty of Philosophy \\ University of Belgrade \\ Čika Ljubina 18-20 \\ 11000 Belgrade \\ Serbia \\ E-mail: nsamardz@f.bg.ac.rs
}

\section{Summary}

Mediation of Robert Sutton during the Passarowitz Peace Conference in 1718 has confirmed the Britain's new role in international relations. At the same time France approached Britain, confirming a new course of its foreign policy. However, such approaching threatened to spoil relations between Britain and Austria. From the last decades of the seventeenth century, British alliance with Austria was highly significant, and therefore as the mediator in peace talks between Austria and Turkey was elected Robert Sutton, already experienced as British Ambassador to the Ottoman Porte. Britain expected that both sides will take into account his diplomatic experience and political credibility. His role turned out to become additionally significant within highly complicated international circumstances. Particularly concerned with the Russian military involvement in the area of Mecklenburg and the strengthening of Russia in the Baltic, as well as with renewed ambitions of Spain in Italy, British government sought to simultaneously control and speed up the Passarowitz peace negotiations.

Sutton's reports to the British government confirmed that during the 1718 negotiations in Passarowitz the same diplomatic protocol was applied as during the previous 1699 conference in Karlowitz (Sremski Karlovci). The Ottoman Porte, on the other hand, was ultimately forced to apply practices of modern European 
diplomacy with compliance to the general bilateral principle in peace process, including the protocol. British mediation also revealed its future interests in the eastern Mediterranean, which included the withdrawal of Venice from the important spheres of politics and business in the Ottoman Empire. The Passarowitz peace agreement from 1718 officially reduced Venice to a second-rate power ranking, and the British traders were enabled to take over important pieces of Venetian eastern markets.

Keywords: Robert Sutton, Passarowitz, diplomacy, Porte, Abraham Stanyan, negotiations 